\title{
Effect of Intestinal Helminths on the Protein Content of Heavy Metals Polluted Tissues of Lethrinus mahsena Fish
}

\section{Amaal Hassan $^{1,2 *}$, Salim M El-Hamidy ${ }^{1}$, Najla Al-Saud ${ }^{1}$, Sabah M Hassan ${ }^{1,3}$, Shaikh AM ${ }^{1,4}$, Khalid Mohammed Algamdi ${ }^{1}$, Hanan Alhelali $^{1}$ and Habeeb M Al-Solami ${ }^{1}$}

${ }^{1}$ Biology Department, Science College, King Abdulaziz University, Jeddah, Saudi Arabia

${ }^{2}$ Zoology Department, Faculty of Science, Sohag University, Sohag, Egypt

${ }^{3}$ Department of Genetics, Faculty of Agriculture, Ain Shams University, Cairo, Egypt

${ }^{4}$ Princess, Doctor Najla Bint Saud Al-Saud Distinguished Research Centre for Biotechnology, Jeddah, Saudi Arabia

*Corresponding Author: Amaal Hassan, Associate professor of parasitology, Biology Department, Science College, King Abdulaziz University, Jeddah, Saudi Arabia.

DOI: 10.31080/ASMS.2020.04.0549
Received: January 22, 2020

Published: January 31, 2020

(C) All rights are reserved by Amaal

Hassan., et al.

\begin{abstract}
Fish are valued as an ideal source of high-quality proteins, which contain large quantities of essential amino acids. The present investigation is designed to study the effect of intestinal helminths in the fish; Single, double and triple helminths infection on the protein content of fish Lethrinus mahsena in the presence of some heavy metals (HMs). In this study, total of 130 emperor fish were collected between November 2015 and May 2016 from the coast of Jeddah. The concentration of the HMs in the infected and uninfected fish was analyzed using the atomic flame absorption spectrometer. Total proteins were extracted from infected and uninfected fish tissues and separated by $12 \%$ of SDS-PAGE. The results revealed that individual cestodes and triple infection caused lower concentrations of $\mathrm{As}, \mathrm{Cd}, \mathrm{Cu}$ and $\mathrm{Fe}$ in fish tissues. While double lesions have caused a decrease in the concentration of $\mathrm{Cd}$ and $\mathrm{Cu}$. There were no significant differences between the protein contents of infected and uninfected fish. This indicates that the presence of intestinal worms in the fortified intestine can reduce the harmful effect of accumulated HMs on the protein content of fish despite HMs contamination.
\end{abstract}

Keywords: Helminths; Heavy Metals; Lethrinus mahsena; Protein; Infection; Contamination

\section{Introduction}

Fish is an important source of premium animal protein with large amounts of essential amino acids. About 20,000 to 30,000 fish species have been identified and each of the species has adopted few helminthes species [1]. Environmental pollution caused by heavy metals (HMs) is a serious threat to the land and marine environment. The HMs such as cadmium (Cd) and lead (Pb) are not nutritionally necessary in high concentrations, and if found in the body at high concentrations, they are harmful to health not only for animals but also for human beings [2]. The HMs can enter fish in three ways: they can be taken directly from the surrounding waters through the skin and gill of the fish, or by absorbing toxic HMs from dirty and contaminated food. The HMs can then enter the bloodstream of fish, accumulate in the tissues of the liver of the fish, and 
can be biologically converted, released or consumed by humans through the food chain [3]. There are very few parasites present in the host, and it has been shown that helminths contain very high concentrations of HMs and cause toxicity [4,5]. The relationship between marine pollution and parasites can be used as a sign to check water quality, which is the most important consideration today. Intestinal parasites in fish obtain heavy mineral deposits at higher concentrations compared to the host tissues [6]. Regardless of the accumulation of natural toxins in parasites, they also play an important role in changing the fate of the chemicals present in the host [7]. Therefore, it is necessary for public health to determine the minimum concentration of HMs in the tissues of fish that humans use. The long exposure to HM pollutants interferes with the physiological, behavioral and biochemical conditions of the host and changes the state of parasites [8]. The accumulation of HMs in fish cells and tissues harms consumers, including humans. This study aimed to determine the toxicity of HMs due to single, double and triple intestinal parasitic infections on Lethrinus mahsena fish tissues and its effect on the protein content of infected fish tissues.

\section{Materials and Methods}

The L. mahsena samples were collected from Ras Mehsen, Jeddah, Saudi Arabia, contaminated with industrial waste from neighboring factories (Figure 1). From November 2015 to May 2016, 100 fish were randomly collected from the above collection site. After dissecting fresh fish, the presence of parasites was examined under a microscope. Parasites were collected and identified in the affected organs [9].

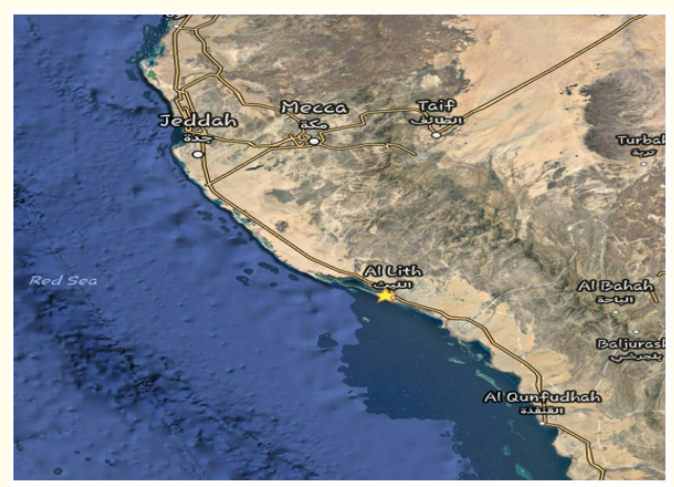

Figure 1: Map of the studied sites (google map).

\section{Heavy metals analysis}

Heavy metals were extracted from seawater using concentrated hydrochloric acid ( $\mathrm{HCl}$ ), and concentrations of $\mathrm{Pb}, \mathrm{Cd}, \mathrm{Fe}, \mathrm{Cu}, \mathrm{As}$ and Zn were determined according to the Ali., et al [10]. The samples were then analyzed using the FAAS atomic absorption test. FAAS discovered HM concentrations with Varian 5-AAS Jena Spectrometer Analysis [9,11].

\section{Electrphoresis for protein in fish muscles}

The Total protein content was extracted from the fish muscles according to Smith [12]. total protein contents were estimated according to Laemmli [13] and were resolved on 12\% SDS-PAGE along with wide molecular weight standard (Sigma). Gels were imaged using the Bio-Rad gel documentation system. Data analysis was obtained by Bio-Rad Quantity 1, 4.0.3 software version.

\section{Statistical analysis}

Statistical analysis was completed by student $t$-test with SPSS (version 19).

\section{The results}

\section{Heavy metal analysis of uninfected and infected fish}

Emperor fish, Lethrinus mahsena muscle tissues, were examined for the existence of different types of heavy metals; $\mathrm{As}, \mathrm{Cd}, \mathrm{Cu}$, $\mathrm{Fe}, \mathrm{Pb}$ and $\mathrm{Zn}$ using FAAS of single Trematoda (T), Cestoda (C) and Nematoda $(\mathrm{N})$, double Trematoda+ Cestoda $(\mathrm{T}+\mathrm{C})$; Trematoda+ Nematoda $(\mathrm{T}+\mathrm{N})$ and Cestoda + Nematoda $(\mathrm{C}+\mathrm{N})$ as well as triple $(\mathrm{T}+\mathrm{C}+\mathrm{N})$ infections, contrasted to uninfected fish.

Changes in the concentrations of HMs in fish tissues due to individual infection of the intestinal parasites are shown in table 1 . Arsenic analysis showed a marked increase in its concentration in individual infected fish with $\mathrm{T}$ and $\mathrm{N}$. The concentrations of $\mathrm{Cd}$ and $\mathrm{Cu}$ decreased significantly in affected fish. Iron decreased significantly in single fish with $\mathrm{C}$ and significantly increased in fish with $\mathrm{T}$ compared to healthy fish. Lead increased significantly in single fish tissue ( $\mathrm{C}$ and $\mathrm{N}$ ). The VI trace mineral analyzed was zinc. In fish tissues that infected with single $\mathrm{C}$ and $\mathrm{N}$, the $\mathrm{Zn}$ concentration was significantly increased compared to healthy fish. 
Effect of Intestinal Helminths on the Protein Content of Heavy Metals Polluted Tissues of Lethrinus mahsena Fish

\begin{tabular}{|c|c|c|c|c|c|c|}
\hline Uninfected & Inf. with Trematodea & $P$ value & Inf. with Cestodea & $P$ value & Inf. with Nematodea & $P$ value \\
\hline \multicolumn{7}{|l|}{ As } \\
\hline $386.03 \pm 50.97$ & $902.04 \pm 28.20$ & $0.000^{*}$ & $373.25 \pm 20.45$ & 0.129 & $1025.45 \pm 217.37$ & $0.001^{*}$ \\
\hline \multicolumn{7}{|l|}{$\mathrm{Cd}$} \\
\hline $0.017 \pm 0.008$ & $0.005 \pm 0.002$ & $0.000^{*}$ & $0.005 \pm 0.004$ & $0.03^{*}$ & $0.003 \pm 0.001$ & $0.008^{*}$ \\
\hline \multicolumn{7}{|l|}{$\mathrm{Cu}$} \\
\hline $0.096 \pm 0.046$ & $0.027 \pm 0.013$ & $0.057 *$ & $0.005 \pm 0.001$ & $0.020^{*}$ & $0.023 \pm 0.010$ & $0.026^{*}$ \\
\hline \multicolumn{7}{|l|}{$\mathrm{Fe}$} \\
\hline $2.949 \pm 0.954$ & $6.985 \pm 5.029$ & $0.018^{*}$ & $0.191 \pm 0.071$ & $0.019 *$ & $4.353 \pm 2.558$ & 0.248 \\
\hline \multicolumn{7}{|l|}{$\mathrm{Pb}$} \\
\hline $0.076 \pm 0.009$ & $0.103 \pm 0.014$ & 0.210 & $0.128 \pm 0.001$ & $0.001^{*}$ & $0.105 \pm 0.009$ & $0.011^{*}$ \\
\hline \multicolumn{7}{|l|}{$\mathrm{Zn}$} \\
\hline $0.948 \pm 0.326$ & $1.436 \pm 0.876$ & 0.441 & $3.014 \pm 2.596$ & $0.032^{*}$ & $3.640 \pm 2.527$ & $0.002^{*}$ \\
\hline
\end{tabular}

Table 1: Heavy metals concentrations (mg/g) in Lethrinus mahsena muscle tissues single infection of Helminths.

Significant $* P \leq 0.05$.

Table 2 shows the metals concentration in the double infected fish tissues. Analysis of As in muscle tissues revealed a significantly high concentration in the double $\mathrm{T}+\mathrm{C}$ and $\mathrm{C}+\mathrm{N}$ infected fish. $\mathrm{Cd}$ in $\mathrm{C}+\mathrm{N}$ infected fish tissues revealed a significantly higher concentration than healthy fish. Cadmium concentration in the muscle tissues of double $(\mathrm{T}+\mathrm{C}$ and $\mathrm{T}+\mathrm{N})$ infected fish significantly decreased.
Copper concentration significantly declined in double infected fish tissues. Iron was significantly lower in double $(\mathrm{T}+\mathrm{C}$ and $\mathrm{T}+\mathrm{N})$ infected fish. Lead was found to be significantly increased in the fish tissues of double $(\mathrm{T}+\mathrm{C})$ infected fish. In the infected fish tissues with $\mathrm{T}+\mathrm{C}$ and $\mathrm{T}+\mathrm{N}$, the $\mathrm{Zn}$ concentration increased significantly compared to healthy fish.

\begin{tabular}{|c|c|c|c|c|c|c|}
\hline Uninfected & Inf. with $(\mathrm{T}+\mathrm{C})$ & $P$ value & Inf. with $(\mathrm{T}+\mathrm{N})$ & $P$ value & Inf. with $(\mathrm{C}+\mathrm{N})$ & $P$ value \\
\hline \multicolumn{7}{|l|}{ As } \\
\hline $386.03 \pm 50.97$ & $567.30 \pm 195.79$ & $0.010^{*}$ & $476.02 \pm 140.70$ & 0.535 & $821.58 \pm 219.86$ & $0.004^{*}$ \\
\hline \multicolumn{7}{|l|}{$\mathrm{Cd}$} \\
\hline $0.017 \pm 0.008$ & $0.005 \pm 0.001$ & $0.015^{*}$ & $0.008 \pm 0.003$ & $0.019^{*}$ & $0.061 \pm 0.053$ & $0.002^{*}$ \\
\hline \multicolumn{7}{|l|}{$\mathrm{Cu}$} \\
\hline $0.096 \pm 0.046$ & $0.015 \pm 0.007$ & $0.056^{*}$ & $0.010 \pm 0.006$ & $0.029 *$ & $0.059 \pm 0.036$ & $0.027^{*}$ \\
\hline \multicolumn{7}{|l|}{$\mathrm{Fe}$} \\
\hline $2.949 \pm 0.954$ & $0.615 \pm 0.132$ & $0.055^{*}$ & $0.159 \pm 0.042$ & $0.056^{*}$ & $2.455 \pm 2.287$ & 0.699 \\
\hline \multicolumn{7}{|l|}{$\mathrm{Pb}$} \\
\hline $0.076 \pm 0.009$ & $0.112 \pm 0.010$ & $0.011^{*}$ & $0.104 \pm 0.015$ & 0.109 & $0.099 \pm 0.022$ & 0.817 \\
\hline \multicolumn{7}{|l|}{$\mathrm{Zn}$} \\
\hline $0.948 \pm 0.326$ & $5.469 \pm 2.675$ & $0.000^{*}$ & $5.270 \pm 2.942$ & $0.000 *$ & $2.481 \pm 1.161$ & 0.075 \\
\hline
\end{tabular}

Table 2: Heavy metals concentrations (mg/g) in Lethrinus mahsena muscle tissues in double infection of helminths Significant $* P \leq 0.05$. 
As shown in table 3, mineral analysis of triple infected fish tissues shows a significant decrease in arsenic. On the other hand, $\mathrm{Cd}$, $\mathrm{Cu}$ and Fe were created for a big cut. Lead and zinc are significantly increased compared to healthy fish. The concentration of HMs in the collected seawater samples is: As $56.75, \mathrm{Zn} 14.13, \mathrm{~Pb} 0.89$, Fe 0.12, Cd 0.08, and Cu 0.08 mg / L.

\begin{tabular}{|l|c|c|}
\hline Uninfected & Triple infection & $P$ value \\
\hline As & \multicolumn{1}{|l|}{} \\
\hline $386.03 \pm 50.97$ & $318.733 \pm 47.624$ & 0.172 \\
\hline $\mathrm{Cd}$ & $0.007 \pm .0 .001$ & $0.022^{*}$ \\
\hline $0.017 \pm 0.008$ & $0.005 \pm 0.001$ & $0.012^{*}$ \\
\hline $\mathrm{Cu}$ & $0.243 \pm 0.042$ & $0.011^{*}$ \\
\hline $0.096 \pm 0.046$ & & \\
\hline $\mathrm{Fe}$ & $0.119 \pm 0.004$ & $0.001^{*}$ \\
\hline $2.949 \pm 0.954$ & & \\
\hline $\mathrm{Pb}$ & & $0.003^{*}$ \\
\hline $0.076 \pm 0.009$ &
\end{tabular}

Table 3: Heavy metals concentrations (mg/g) in triple infected Lethrinus mahsena

Significant $* P \leq 0.05$.

\section{Protein binding patterns in uninfected and infected fish}

Using the total proteins extracted from uninfected and infected methylated muscle tissue, SDS-PAGE discovered some biochemical genetic differences between them. The infected fish were categorized as follows: single nematode infection $(\mathrm{N})$, trematode $(\mathrm{T})$ and cestode $(\mathrm{C})$, double infection with $\mathrm{T}+\mathrm{C}, \mathrm{C}+\mathrm{N}$ and $\mathrm{T}+\mathrm{N}$ and triple infection $(\mathrm{T}+\mathrm{N}+\mathrm{C})$.

As shown in table 4, in SDS-PAGE of total protein extracted from the tissues of uninfected and infected fish, a total of 20 ranges were discovered with different molecular weights ranging from 2.302 to $363.462 \mathrm{kDa}$. Seven common (single) ranges $(5,6,9,15,16,17$ and 19) with molecular weights of 202.225 and 169.156, 107.222, $38.968,26.47,20.829$ and $12.135 \mathrm{kDa}$, respectively. The resulting polymorphic bands are $14(1,2,3,4,7,8,10,11,12,13,14,18$, 20 and 21), the molecular weight is $362.308,340,319.385,275$, 152.106, 132.697, 88.192, 77.549, 61.236, 54.843, 48.286, 16.545, 7.659 and 2.302. The results indicate that no unique group identified the infected and uninfected tissues. The tissues of the fish with trematode intestinal infection were assigned in the absence of bar numbers. This strip can be considered a negative sign for a 14-point crack infection with a molecular weight of 48,286 kDa. However, the number of protein-based phylogeny shown in figure 2 separates uninfected, single and triple infected fish in four different groups, but not completely.

\begin{tabular}{|l|c|c|c|c|c|c|c|c|c|c|}
\hline NAME & M.W. KDA & $\mathbf{U}$ & $\mathbf{T}$ & $\mathbf{C}$ & $\mathbf{N}$ & $\mathbf{T}+\mathbf{C}$ & $\mathbf{T}+\mathbf{N}$ & $\mathbf{C}+\mathbf{N}$ & $\mathbf{T}+\mathbf{C}+\mathbf{N}$ & $\mathbf{T}+\mathbf{C}+\mathbf{N}$ \\
\hline BAND 1 & 362.308 & 1 & 0 & 0 & 1 & 1 & 0 & 0 & 1 & 1 \\
\hline BAND 2 & 340 & 1 & 0 & 1 & 0 & 1 & 0 & 0 & 0 & 0 \\
\hline BAND 3 & 319.385 & 0 & 1 & 1 & 1 & 0 & 0 & 0 & 1 & 1 \\
\hline BAND 4 & 275 & 0 & 1 & 1 & 1 & 1 & 0 & 0 & 1 & 1 \\
\hline BAND 5 & 202.225 & 1 & 1 & 1 & 1 & 1 & 1 & 1 & 1 & 1 \\
\hline BAND 6 & 169.156 & 1 & 1 & 1 & 1 & 1 & 1 & 1 & 1 & 1 \\
\hline BAND 7 & 152.106 & 0 & 1 & 1 & 1 & 1 & 0 & 1 & 0 & 0 \\
\hline BAND 8 & 132.697 & 1 & 1 & 0 & 0 & 1 & 1 & 1 & 0 & 0 \\
\hline BAND 9 & 107.222 & 1 & 1 & 1 & 1 & 1 & 1 & 1 & 1 & 1 \\
\hline BAND 10 & 88.192 & 0 & 1 & 1 & 1 & 0 & 0 & 0 & 1 & 1 \\
\hline BAND 11 & 77.549 & 0 & 1 & 0 & 0 & 0 & 1 & 0 & 1 & 1 \\
\hline BAND 12 & 61.236 & 1 & 1 & 0 & 0 & 1 & 1 & 1 & 1 & 1 \\
\hline BAND 13 & 54.843 & 0 & 1 & 1 & 1 & 0 & 0 & 0 & 1 & 1 \\
\hline BAND 14 & 48.286 & 1 & 0 & 1 & 1 & 1 & 1 & 1 & 1 & 1 \\
\hline BAND 15 & 38.968 & 1 & 1 & 1 & 1 & 1 & 1 & 1 & 1 & 1 \\
\hline BAND 16 & 26.47 & 1 & 1 & 1 & 1 & 1 & 1 & 1 & 1 & 1 \\
\hline BAND 17 & 20.829 & 1 & 1 & 1 & 1 & 1 & 1 & 1 & 1 & 1 \\
\hline BAND 18 & 16.545 & 1 & 1 & 0 & 0 & 1 & 1 & 1 & 1 & 1 \\
\hline BAND 19 & 12.135 & 1 & 1 & 1 & 1 & 1 & 1 & 0 & 1 & 1 \\
\hline BAND 20 & 7.659 & 0 & 0 & 1 & 1 & 0 & 1 & 1 & 1 & 1 \\
\hline BAND 21 & 2.302 & 1 & 1 & 1 & 1 & 1 & 1 & 1 & 1 & 1 \\
\hline
\end{tabular}

Table 4: Summary of densitometric analysis for total protein profiles from uninfected (U) and infected.

Lethrinus mahsena muscle tissues as single-infected with trematode (T), cestode (C) and nematode $(\mathrm{N})$, double-infected with $\mathrm{T}+\mathrm{C}, \mathrm{T}+\mathrm{N}$ and $\mathrm{C}+\mathrm{N}$, as well as the triple-infected $(\mathrm{T}+\mathrm{N}+\mathrm{C})$. 


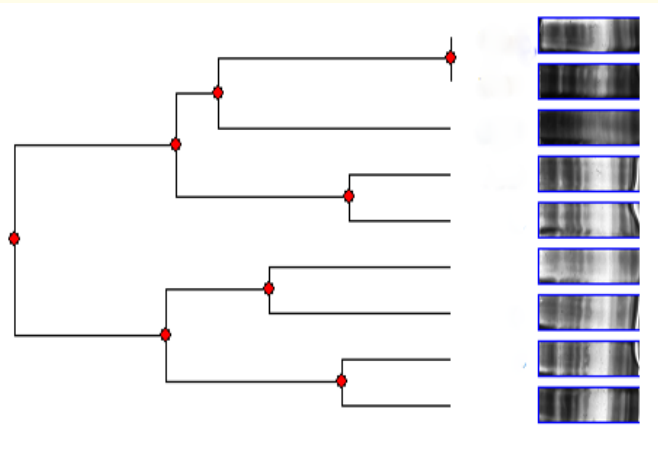

\begin{tabular}{|llllll|}
\hline 0.75 & 0.80 & 0.85 & 0.90 & 0.95 & 1.00
\end{tabular}

Figure 2: Protein-based neighbor-joining phylogenetic tree for uninfected (U) and infected Lethrinus mahsena tissues as singleinfected with trematodes $(\mathrm{T})$, cestodes $(\mathrm{C})$ and nematodes $(\mathrm{N})$,

double-infected with $\mathrm{T}+\mathrm{C}, \mathrm{T}+\mathrm{N}$ and $\mathrm{C}+\mathrm{N}$, as well as the triple-infected $(\mathrm{T}+\mathrm{N}+\mathrm{C})$.

\section{Discussion}

Saltwater fish around the world make up the most abundant fish food. The protein content of healthy fish is considered relatively stable against clear species. In general, there are no significant seasonal differences in the protein content of fish. Parasites play a very important role in the accumulation of toxic HMs in the body. Thus, they can act as host metal basins and thus support the supply of high concentrations of HMs [14-16].

Prolonged exposure to pollutants can lead to physiological, behavioral, and biochemical changes in the host that can affect the prevalence and density of parasites [8]. Previous studies that discussed the absorption and collection of pollutants in fish tissues were achieved using fish parasites. They accumulate minerals thousands of times higher than the host's body. The internal batteries were examined for efficient metal accumulation [17].

In this study, intestinal parasites (Trematoda, Cestoda and Nematoda) were found to be single or double (Trematoda, Cestoda $\mathrm{T}+\mathrm{C}$, Trematoda, Nematoda $\mathrm{T}+\mathrm{N}$, Cestoda, Nematoda C $+\mathrm{N}$ ) or triple. Individual infections with single, double and triple infections have a greater impact on the mineral content of fish tissues.
They cause a decrease in the concentrations of $\mathrm{As}, \mathrm{Cd}, \mathrm{Cu}$ and $\mathrm{Fe}$ in fish infected with cestodes only, and triple $(\mathrm{T}+\mathrm{C}+\mathrm{N})$ and decreasing in the concentrations of $\mathrm{Cd}$ and $\mathrm{Cu}$ in the double infected fish compared with healthy one.

In our previous studies, $\mathrm{Fe}, \mathrm{Cd}, \mathrm{Cu}$ and $\mathrm{Pb}$ concentrations were established to significantly increase intestinal parasites studied from the tissues of Emperor fish. In addition, the bioaccumulation factor of parasites was found to be significantly higher in parasites associated with fish tissues [9]. Intestinal parasites have been shown to accumulate more minerals than fisheries parasites [18]. Otherwise, cestodes can interfere with the host's metal proteins, increasing the toxicity of the metal. Poisoning HMs by absorbing not only mineral-binding proteins, but also some fats and proteins that are essential to metabolic requirements. This indicates an increase in several concentrations of HMs in the infected fish associated with the non-infected fish. The increase in HMs in fish through infection can be attributed to the competitive reaction of parasites and hosts $[19,20]$.

Some parasites accumulate HMs in the body, which play an important role in purifying the organism. Intestinal parasites can reduce the level of HMs in Emperor fish, which can be beneficial to fish by allowing them to withstand high levels of HMs. According to previous studies, infection with nematodes appears to be good indicators of water pollution. This discovery can be strengthened by current results that confirm the parasite's ability to store HMs such as iron, cadmium, copper and lead. These data, of course, illustrate the benefits of parasites in the ocean for potential applications such as indicators for warning of HMs contamination [4,5,9].

Fluctuations in the muscle protein content due to parasitic infections include: some protein ranges disappear, the existing band disappears, or a new band presence appears. However, this difference in protein bands can be considered a reflection of the effects of stress on the levels of ribose and RNA, which influence protein synthesis [21,22].

In the present study, small differences in protein content were observed between infected and uninfected fish. These results are consistent with previous investigations and indicated that proteins in the muscles of contaminated fish will have no effect except in the case of severe loss of vitality, including glycogen and fat [2325]. This may be due to tissue fixation techniques that serve as host 
methods for adapting to parasite attacks [26]. Solomon et al. [27], added that dual diseases have a greater impact on biochemical changes than individual pollution. The pollution resulted in three times the results of the pollution similar to the nutritional value of the fish. Triple infections were steadily strong in protein content [28].

Several studies have also addressed the relationship between HMs contamination and biosynthesis in uninfected fish. The high accumulation of HMs interferes with the biological activity of catfish by disturbing the ribosome and nucleic acids, which reduces the biosynthesis of protein, especially in muscle tissue. HMs have a limited effect on the biosynthesis of protein due to its effects on RNA and ribosome activity in uninfected catfish. High mercury and Cadmium concentrations in catfish muscles can reduce the nutritional quality of tissue proteins. $\mathrm{Cd}$ and $\mathrm{Pb}$ adversely affect increased protein efficiency in the fish body, chemical composition and muscle region in catfish [2]. Abdul-Hamid and Al-Ayouti [29] also found a negative relationship between the organic protein content and the lead content in uninfected fish. Therefore, from a public health point of view, it is important to measure the contamination of HMs from fish used in human depletion [8].

\section{Conclusion}

In the current study, we can conclude that with a single infection restricted by, all double and triple infections further affect the mineral content of fish tissues. Individual injuries and triple infection $(\mathrm{T}+\mathrm{C}+\mathrm{N})$ caused a decrease in $\mathrm{As}, \mathrm{Cd}, \mathrm{Cu}$ and Fe concentrations in the tissues of Lethrinus mahsena. On the other hand, all double infection caused a lower $\mathrm{Cd}$ and $\mathrm{Cu}$ concentration compared to the uninfected. Concentrations of $\mathrm{Cd}, \mathrm{Cu}, \mathrm{Fe}, \mathrm{Pb}$, and $\mathrm{Zn}$ from uninfected L. mahsena were found below the SASO (Saudi Standards Organization) limits, except for As. There is a slight difference between the protein polymer strips of infected and uninfected fish, except for those with single trematodes infection. This indicates that the presence of intestinal parasites in the small intestine of $L$. mahsena can lead to the accumulation of HMs in their body, which may reduce the harmful effects of HMs on fish proteins. Parasitologists and marine environmental toxicologists must work together to conduct further research in this field.

\section{Bibliography}

1. Rohde K. "Ecology of marine parasites". University of Queensland Press (St. Lucia and New York) (1982): 230.
2. Habib SA and Abou Shehatta, S "Effect of Heavy Metals Pollution on Protein Biosynthesis in Catfish". JWRP Jewish Women's Renaissance Project 5 (2013): 555-562.

3. Mziray PK and Kimirei IA. "Bioaccumulation of heavy metals in marine fishes (Siganus sutor, lethrinus harak, and Rastrelliger kanagurta) from Dar es Salaam Tanzania". Regional Studies in Marine Science 7 (2016): 72-80.

4. Sures B., et al. "Intestinal fish parasites as heavy metal bioindicators: A comparison between Acanthocephalus lucii (Palaeacanthocephala) and the zebra mussel, Dreissena polymorpha". Bulletin of Environmental Contamination and Toxicology 59 (1997): 14-21.

5. Zaghloul K. "Usage of zinc and calcium in inhibiting the toxic Effect of copper on the African catfish, Clarias gariepinus". Journal of the Egyptian-German Society of Zoology 35 (2001): 99-119.

6. Sures B., et al. "Parasites as accumulation indicators of heavy metal pollution". Parasitology Today 15 (1999): 16-21.

7. Evans DW., et al. "The effect of digenean (Platyhelminthes) infections on heavy metal concentrations in Littorina littorea". Journal of the Marine Biological Association of the United Kingdom 81 (2001): 349-350.

8. Khan R and Thulin J. "Influence of pollution on parasites of aquatic animals”. Advances in Parasitology 30 (1991): 201-238.

9. Hassan A., et al. "Role of parasitic helminths in bioremediating some heavy metal accumulation in the tissues of Lethrinus mahsena". Turkish Journal of Fisheries and Aquatic Sciences 18 (2018): 435-443.

10. Ali AA., et al. "Investigation of Heavy Metals Pollution in Water, Sediment and Fish at Red Sea-Jeddah Coast-KSA at two different locations". Journal of Applied Environmental and Biological Sciences 1 (2011): 630-637.

11. Hassan A., et al. "Impact of nematode helminths on metal concentrations in the muscles of koshar fish, Epinephelus summana, in Jeddah, Saudi Arabia”. JOBAZ 74 (2016): 56-61.

12. Smith D. "Fish Muscle Proteins: Extraction, Quantitation, and Electrophoresis. In: Nielsen S.S. (eds) Food Analysis Laboratory Manual". Food Science Texts Series. Springer, Boston, MA (2010).

13. Laemmli UK. "Cleavage of structural proteins during the assembly of the head of bacteriophage T4". Nature 227 (1970): 680-685. 
14. Sures B. "Host-parasite interactions from an ecotoxicological perspective”. Parassitologia 49 (2007): 173-176.

15. Azmat R, et al. "Natural bioremediation of heavy metals through nematode parasite of fish". Biotechnology 1 (2008): 139-143.

16. Eissa IA., et al. "Bioremediation for heavy metals in some Red Sea fishes in Suez, Egypt”. Suez Canal Veterinary Medicine Journal 2 (2012): 341- 356.

17. Sures B "Environmental parasitology: Relevancy of parasites in monitoring environmental pollution". Trends in Parasitology 20 (2004):170-177.

18. Nachev M., et al. "Comparison of the metal accumulation capacity between the acanthocephalan Pomphorhynchus laevis and larval nematodes of the genus Eustrongylides sp. infecting barbel (Barbus barbus)". Parasite Vector 6 (2013): 1-8.

19. Samuel D and George PV "Mineral constituents of freshwater fish Channa striatus infected with acanthocephalan parasite, Pallisentis nagpurensis". Indian Journal of Fisheries 47 (2000): 215-224.

20. Oyoo-Okoth E., et al. "Parasites modify sub- cellular partitioning of metals in the gut of fish". Aquatic Toxicology 106 (2012): 76-84.

21. Guyton AC. "Text book of medical physiology" 2nd edition. Saunders Philadelphia and London. (1961): 141-145.

22. De Burin AD. "Biochemical toxicology of environmental agents". Elsevier, Elsevier; Amsterdam, Netherlands (1976): 1554.

23. Mehdi DS. "Effect of parasites on the biochemical constituents of fishes Liza abu”. M.Sc. Thesis, University of Basrah (1989): 98.

24. Al-Hadithi IAW., et al. "Effect of intensity of Infection with parasites on protein content in Liza abu (Heckle)". Basrah Journal of Agricultural Sciences 3 (1990): 209-218.

25. Ali AH. "Pathological effects of helminths parasitic on some local fishes". M.Sc. thesis, College of Agriculture, Basrah University (2001).

26. Kumar PA. "Biochemical effects on protein and free amino acid metabolism in Catla catla and Labeo rohita due to Pallisentis nagpurensis infection".| AIJRFANS 6 (2014): 82- 85.
27. Soliman MF. "Parasitological aspects and biochemical changes of infected cultured tilapia [Oreochromis hybrid". Acta Ichthyologica Et Piscatoria 34 (2004): 21-32.

28. Al-Khayat BH and Al-Salehi MS. "The effect of parasitism on some biochemical compounds in liver of Acanthobrama marmid infected with Pseudochetosoma salmincola (Digenea) and Ligula intestinalis (Tapeworme)". Rafidain Journal of Science 18 (2007): 30-40.

29. Abdelhamid AM and El-Ayouty SA "Effect on catfish (Clarias lazera) composition of ingestion rearing water contaminated with lead or aluminum compounds". Arch Tierernahr 41 (1991): 757-763.

\section{Assets from publication with us}

- Prompt Acknowledgement after receiving the article

- Thorough Double blinded peer review

- Rapid Publication

- Issue of Publication Certificate

- High visibility of your Published work

Website: https://www.actascientific.com/

Submit Article: https://www.actascientific.com/submission.php Email us: editor@actascientific.com

Contact us: +919182824667 